\title{
Esophageal Granular Cell Tumor
}

\author{
Vedat Goral $^{1}$, Sila Yilmaz Erozbek ${ }^{2}$, Kerem Mert Goral ${ }^{3}$, Burcu Saka ${ }^{2}$ \\ ${ }^{1}$ Istanbul Medipol University Medical School Department of Gastroenterology, Istanbul. \\ ${ }^{2}$ Istanbul Medipol University Medical School Department of Pathology, Istanbul \\ ${ }^{3}$ Yeditepe Medipol University School of Medicine, Istanbul
}

\section{ABSTRACT}

Esophageal granular cell tumors (GCTs) are rare, often benign tumors of neurogenic origin. Granular cell tumors (GCTs), first described by Abrikossoff in 1926, are rare tumors that occur in various parts of the body [1,2]. They are generally observed in the gastrointestinal tract, less commonly in the thyroid, respiratory tract, female urogenital tract, nervous system, breast, and gastrointestinal (GI) tract [1,2]. Tumors in the gastrointestinal tract represent only 6-10\% of all granular cell tumors, especially the esophagus. In $30-60 \%$ of these cases, the most common location is the esophagus $[1,3]$. These neoplasms are usually solitary and are multifocal lesions in $10 \%$ of cases. Although their clinical course is relatively benign, approximately $2 \%$ of GCTs are malignant.

Keywords: Espohageal granular tumor, Esophagus, Endoscopy

\section{CASE REPORT}

A 32-year-old female patient who applied to the Gastroenterology outpatient clinic due to epigastric pain and dyspepsia complaints had been continuing intermittently for 1 year. In the endoscopic examination, it was observed that there was an erosive raised lesion of 4-5 $\mathrm{mm}$ in diameter at the 33rd $\mathrm{cm}$ from the mouth, and a biopsy was taken from this area and sent to pathology (Figure 1). At the pathologic examination, uniform polygonal or round cells were seen under the microscope (Figure 2). These cells had abundant, fine-grained granular, eosinophilic cytoplasms and small centrally located nuclei. In addition, pseudoepitheliomatous hyperplasia areas were observed in the stratified squamous epithelium of the esophagus (Figure 1,2). Tumor cells were found to be PAS and PAS-D positive in histochemical examination. In the immunohistochemical examination, positive staining was observed with S100 protein and CD68, while GFAP stained negatively (Figure 2). After diagnosis of EGC tumor, endoscopic submukozal disection (ESD) was applied. She is under control and she has not any complaint..

\section{Vol No: 06, Issue: 01}

Received Date: December 08, 2021

Published Date: December 21, 2021

\section{*Corresponding Author}

\section{Prof. Dr. Vedat Goral}

Istanbul Medipol University, Medipol Mega

Hospital Goztepe Mah. 2309 Sk. No: 6 Bagcilar

34214 Istanbul, Turkey.

Tel: 00905335256614.

E-mail: vegoral@hotmail.com

Citation: Goral V. (2021). Esophageal Granular Cell Tumor. Mathews J Gastroenterol Hepatol. 6(1):16.

Copyright: Goral V. (C2021. . This is an open-access article distributed under the terms of the Creative Commons Attribution License, which permits unrestricted use, distribution, and reproduction in any medium, provided the original author and source are credited. 

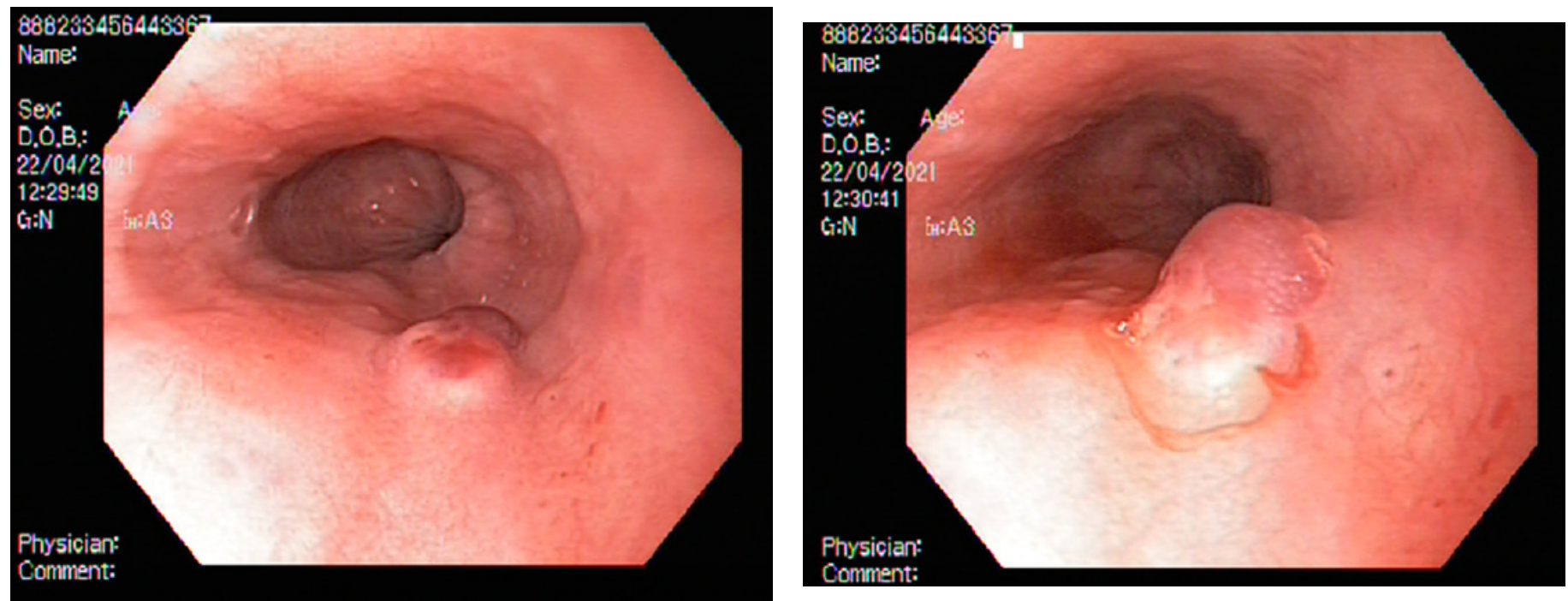

Figure 1: Endoscopic apperance of the lesion at the esophagus

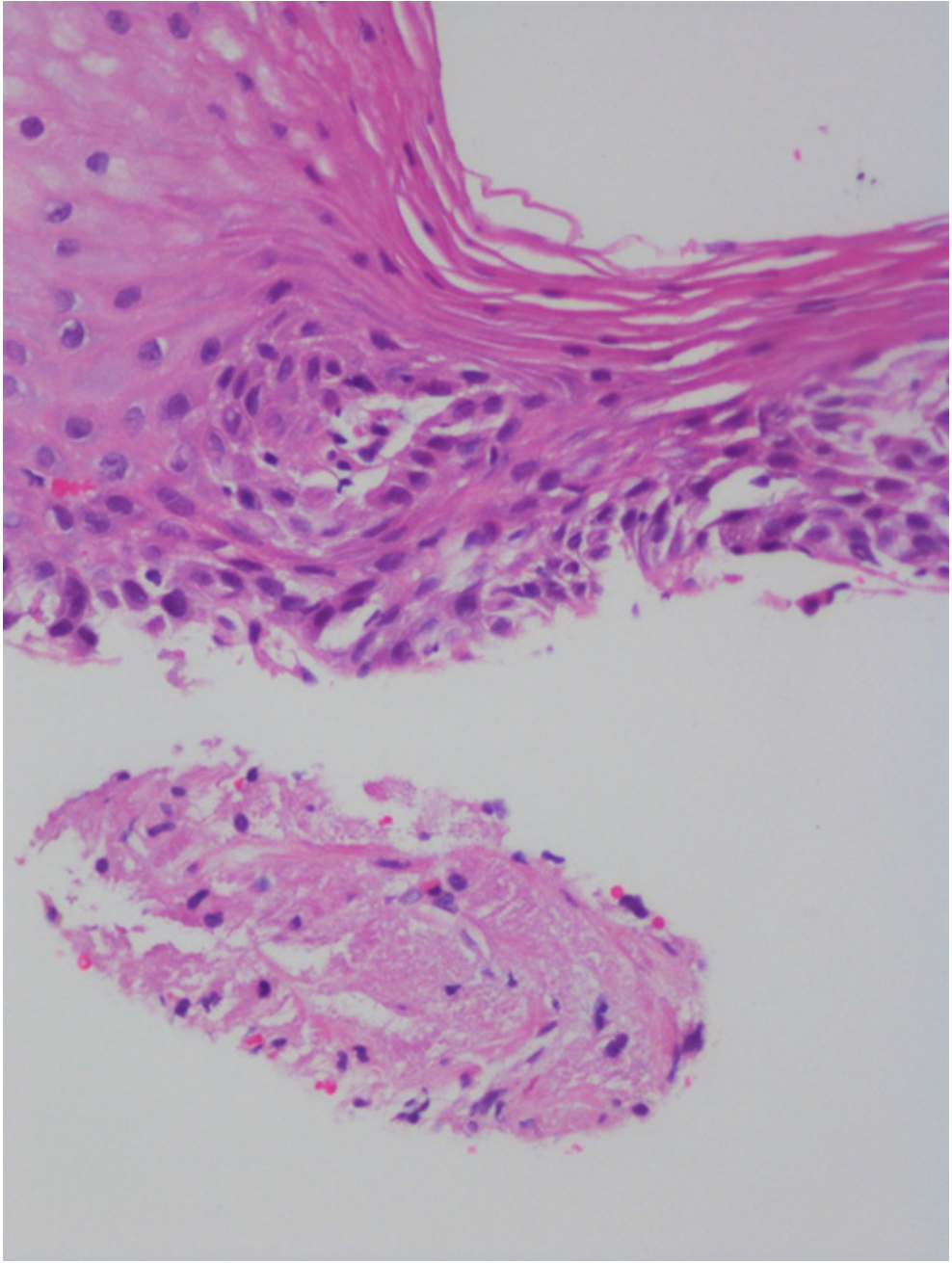

Figure 2: Granular cell tumor-20x-H\&E- Fragment consisting of cells with squamous epithelium on the surface, dark, small nuclei, large, granular and eosinophilic cytoplasm in the subepithelial area suggests the diagnosis of granular cell tumor. 


\section{DISCUSSION}

Esophageal GHTs commonly occur in the fourth to sixth decade of life, with some reports reporting a slightly higher incidence in women [1-3]. Tumors are typically insidious, with most patients asymptomatic at diagnosis. In fact, granular cell tumors are often found incidentally in the investigation of other GI disorders. When tumors are symptomatic, patients most commonly complain of retrosternal pain and discomfort [4-6]. Less reported symptoms include epigastric pain, nausea or vomiting. These symptoms correlate with lesion size with lesions $<20 \mathrm{~mm}$ in diameter.

Malignant esophageal GCTs are extremely rare, with $>40$ cases described in the literature, accounting for only $2 \%$ of cases. Although there is no racial predisposition for benign tumors, one study found that malignant GCTs are most common in African American women [4]. The same study also reported malignant GCTs for benign tumors, most commonly occurring in the soft tissues of the thigh and in the head and neck region. Unlike the more common GCTs of the tongue and skin, those of the esophagus often lack significant malignant potential.

They are determined during upper gastrointestinal endoscopy in patients who apply to the gastroenterology outpatient clinic with dyspeptic complaints. They are usually benign, but because they have malignant potential, histopathological examination is mandatory for definitive diagnosis and treatment. It has been reported that esophageal granular cell tumors are generally asymptomatic in patients with a tumor diameter of less than $10 \mathrm{~mm}$, and the lesions are detected incidentally during upper endoscopy. Dysphagia is the most common complaint in tumors larger than $10 \mathrm{~mm}$ in diameter.

Esophageal granular tumors can sometimes be multiple. Although most of them are benign, histopathological examination is mandatory in terms of diagnosis and treatment, since $1-2 \%$ of the cases are reported to be malignant [5]. They are mostly asymptomatic.

Macroscopically, it is solid, yellow in color. They have malignant potential. 1-2\% of the cases have been reported as malignant. For esophageal GCTs, it has been reported that patients with a tumor diameter of less than $10 \mathrm{~mm}$ are generally asymptomatic, and the lesions are incidentally detected during upper endoscopy. Although most of the cases originate from the mucosa or submucosa, few tumors have been reported to originate from the muscularis propria. Endoscopically, they are usually seen as a submucosal lesion. They are in the form of yellow fluff. The endoscopic appearance may resemble a leiomyoma. Endoscopic USG (EUS) play an important role in diagnosis and treatment. In this way, size, location and depth of invasion can be determined. It has been reported that the definitive diagnosis of granular cell tumors cannot be given by endoscopy and EUS, and histopathology and immunohistochemical examination are mandatory. In some publications, it has been shown that the diagnosis of granular cell tumor is made with EUS-guided fine needle aspiration [7]. In our case, EUS was performed and biopsy was taken from the lesion in the same procedure session.

In differential diagnosis; leiomyoma, GI stromal tumor, esophageal cyst, rhabdomyoma, schwannoma, melanoma, hamartoma, squamous papilloma, squamous cell carcinoma, and metastasis should be considered. A comprehensive study is essential to make an accurate diagnosis and traditionally includes imaging with both EGD (Endoscopic gastro-dudenoscopy) and EUS.

EGD shows the classic appearance of an esophageal GCT as a yellow-gray, intramural lesion lined with normalappearing mucosa, with a yellow-gray consistency, covered with normal-appearing mucosa [5-8]. EUS is used in both the diagnosis and management of esophageal GCTs plays an important role. EUS is invaluable in determining tumor size, location, depth of invasion, and origin of the lesion, and in excluding malignancy and/or lymph node involvement $[3,5,6]$. The typical finding in EUS is hypoechoic, homogeneous, and smooth-edged. tumor within the mucosa or submucosa [5]. Approximately 95\% of esophageal GCTs occur within the mucosa, with the remaining 5\% in the submucosa. Both endoscopy and EUS together can easily distinguish GCTs from malignant lesions, esophageal cysts, inflammatory polyps, and lipomas [7-10]. However, GCTs are more echogenic and show posterior shadowing. However, it can be difficult to reliably distinguish lesions in the mucosa and muscularis propria with EUS and endoscopy alone, and a definitive diagnosis is essential on tissue histopathological examination and IHC.

Small, asymptomatic esophageal GCTs $(<10 \mathrm{~mm}$ in diameter) should be treated conservatively. Therefore, small, asymptomatic esophageal GCTs require annual surveillance with endoscopy and EUS to monitor for growth, recurrence, or malignant transformation. Some authors recommend histological evaluation every 1-2 years, especially in patients with atypical or related feature.

Endoscopic or surgical removal are recommended for 
lesions greater than $10 \mathrm{~mm}$, symptomatic or exhibiting rapid growth, suspected malignancy, or infiltration [9-13]. EMR (endoscopic mucosal resection) and ESD (endoscopic submucosal resection) are well tolerated in patients with lesions $\leq 20 \mathrm{~mm}$ in diameter and no attachment to the muscularis propria. STER (submucosal tunneling endoscopic resection) is the newer technique of choice for lesions 20 $30 \mathrm{~mm}$ in diameter or lesions located in the submucosa but not within the muscularis propria [14]. Recommend the use of STER as it allows an accurate resection, it is safe and less invasive than traditional techniques such as surgical resection, but is cost-effective. The risks of complications such as , mediastinitis, abscess or stricture formation should be addressed.

In conclusion, esophageal GCTs are rare, usually benign tumors of nervous system origin. They can cause dyspeptic complaints and are detected during endoscopy. Observation of characteristic histopathological features is important for diagnosis. Since they have the potential for malignancy, it is recommended to determine tumor location and spread with EUS, and to perform endoscopic resection by providing sound surgical margins.

\section{REFERENCES}

1. Nie L, Xu G, Wu H, Huang Q, Sun Q, et al. (2014). Granular cell tumor of the esophagus: a clinicopathological study of 31 cases. Int J Clin Exp Pathol. 7(7):4000- 4007.

2. Voskuil JH, van Dijk MM, Wagenaar SS, van Vliet AC, Timmer R, et al. (2001). Occurrence of esophageal granular cell tumors in The Netherlands between 1988 and 1994. Dig Dis Sci. 46(8):1610-1614

3. Palazzo L, Landi B, Cellier C, Roseau G, Chaussade S, et al. (1997). Endosonographic features of esophageal granular cell tumors. Endoscopy. 29(9):850-853. doi: 10.1055/s-2007-1004320.

4. Narra SL, Tombazzi C, Datta V, Ismail MK. (2008). Granular cell tumor of the esophagus: report of five cases and review of the literature. Am J Med Sci. 335(5):338341. doi: 10.1097/MAJ.0b013e3181568197.

5. Maekawa H, Maekawa T, Yabuki K, Sato K, Tamazaki Y, et al. (2003). Multiple esophagogastric granular cell tumors. J Gastroenterol. 38:776-780.

6. Nasser H, Ahmed Y, Szpunar SM, Kowalski PJ. (2011). Malignant granular cell tumor: a look into the diagnostic criteria. Pathol Res Pract. 207(3):164- 168. doi: 10.1016/j.prp.2010.12.007.
7. Iwamuro M, Takehiro T, Hiromitsu K, Seiji K, Yoshiro $\mathrm{K}$, et al. (2018). Esophageal granular cell tumors can be differentiated from leiomyomas using endoscopic ultrasonography. Intern Med. 57(11):1509-1515. doi: 10.2169.

8. Yanoma T, Fukuchi M, Sakurai S, Shoji H, Naitoh H, et al. (2015). Granular cell tumor of the esophagus with elevated preoperative serum carbohydrate antigen 199: a case report. Int Surg . 100(2):365-9. doi: 10.9738/ Intsurg-D-13-00195.1.

9. Perçinel S, Savaş B, Yilmaz G, Erinanç H, Küpana Ayva $S$, et al. (2008). Granular cell tumor of the esophagus: three case reports and review of the literature. Turk J Gastroenterol. 19(3):184-188.

10. Chen WS, Zheng XL, Jin L, Pan XJ, Ming-fan Ye. (2014). Novel diagnosis and treatment of esophageal granular cell tumor: report of 14 cases and review of the literatüre. Ann Thorac Surg . 97(1):296-302. doi: 10.1016/j.athoracsur.2013.08.042.

11. Sandler RS, Wood DR, Bozymski EM. (1081). Endoscopic removal of a granular cell tumor of the esophagus. Gastrointest Endosc. 27(2):70-72. doi: 10.1016/s00165107(81)73154-7.

12. Niknam R, Lankarani KB, and Geramizadeh B. (2017). Diagnosis and treatment of esophageal granular cell tumor: A Case report and review of the literature. Case Report in Gastrointestinal Medicine Hindawi. Volume 2017 | Article ID 1071623.

13. Bashir A, Suchi M, Martinez AM, Lerner D. (2021). Esophageal Granular Cell Tumor. J Pediatr Gastroenterol Nutr. 73(6):e126. doi: 10.1097/ MPG.0000000000003274.

14. Sulfang T, Suang S, Guohua L, Xiaowei T, Haitao Q, et al. (2018). Submucosal Tunnel Endoscopic Resection for Esophageal Submucosal Tumors: A Multicenter Study. Gastroenterol Res Pract. 2018:2149564. doi: $10.1155 / 2018 / 2149564$. 